for PPP, special volume on" ADVANCES IN THE INTERPRETATION OF POLLEN AND SPORES IN COPROLITES" ed.: Owen K. Davis. in press 2006

\title{
Iron Age to Medieval entomogamous vegetation and Rhinolophus hipposideros roost in south-eastern Wales (UK)
}

Suzanne A. G. Leroy (1) and Michael J. Simms (2)

1 - Department of Geography and Earth Sciences, Brunel University, Uxbridge UB8 3PH, $U K^{1}$

2 - Department of Geology, Ulster Museum, Botanic Gardens, Belfast BT9 5AB, N. Ireland, $U K^{2}$

${ }^{1}$ Corresponding author, tel.: +44-1895-203178, fax: ++44-1895-203217, e-mail:

Suzanne.Leroy@brunel.ac.uk

${ }^{2}$ fax: ++44-28-9038 3103, e-mail: michael.simms.um@nics.gov.uk 


\begin{abstract}
Karst cave systems are well developed in Wales (UK) and, in some instances, constitute important bat roosts. Ogof Draenen, near Blaenavon in south-east Wales, is the most recent major cave discovery (1994) with already $>70 \mathrm{~km}$ of passages explored spanning a vertical range of $148 \mathrm{~m}$.

With the exception of one small chamber (Siambre Ddu) located directly above the main Ogof Draenen system, very few bats have been noticed inside. Extensive accumulations of guano, attributable to Rhinolophus hipposideros, are however found in parts of the Ogof Draenen system. In places covering many square meters and sometimes building heaps $>0.5 \mathrm{~m}$ thick, these represent volumes not yet found in any other cave system in the British Isles.

Although the date of the abandonment of the main Ogof Draenen system as a bat roost remains unknown, six radiocarbon dates on guano from Ogof Draenen place the occupation in the Iron Age to Medieval period at least. Palynological analysis was undertaken on ten samples distributed through the cave. Comparisons were made with a moss polster and a lake mud sample from the area to provide a first approximation of the regional modern pollen rain and with two modern guano samples, one from Siambre Ddu and one from Agen Allwedd cave (5 $\mathrm{km}$ to the north-west) to provide a temporal comparison with the fossil guano. Agen Allwedd cave currently is one of the largest active roosts for Lesser Horseshoe bats in Britain and lies close to the present northern limit of this endangered species in Europe.

The main results are that

- the cave appears to have been used both as a summer and a winter roost;

- most of the Ogof Draenen guano is formed within c. $1600{ }^{14} \mathrm{C}$ years and, if the largest heap is continuous, it has accumulated within $750{ }^{14} \mathrm{C}$ years, i. e. $0.16 \mathrm{~mm} \cdot \mathrm{year}^{-1}$;

- the fossil guano samples reflect a relatively closed oak forest with more abundant ivy (Hedera) and holly (Ilex) than at present;

- insect-pollinated plants such as Ilex, Acer, Hedera and Impatiens glandulifera are overrepresented in the guano samples;

- in addition to the usual causes of bat roost decline (pesticides, pollution), in the case of Ogof Draenen, we may add entrance blocked by rock collapse and decline of the local forest cover as well as change in its composition.
\end{abstract}

Key words: Rhinolophus hipposideros, bat guano, palynology, Wales, Ogof Draenen, Iron Age to Medieval (get them from GEOREF only) 


\section{Introduction}

Fossil bat guano is a poorly known proxy for the reconstruction of past vegetation, although it is a tool especially valuable for recording the history of entomogamous plants otherwise under-represented in more conventional sedimentary archives. Chiropteran guano may be a very good environment for the preservation of pollen grains and spores and often can be precisely radiocarbon dated. In addition, it represents an unsuspected source of indirect information on the past behaviour of a group of endangered mammals.

Initial interest in this subject was raised by the presence of large bat guano deposits (Rhinolophus hipposideros, Lesser Horseshoe) in a newly discovered cave system (Ogof Draenen) near Blaenavon, in south-east Wales (UK). Very few extant bats have been seen in this cave and an initial Romano-British radiocarbon date soon demonstrated the antiquity of the guano deposits, which subsequently became the subject of a more detailed sampling for palynological analysis.

\section{Guano, palynology and bats}

Guano is a Quichua word for seabird manure, but usage of the word has been extended to bat dung. Bat guano is often better known as an organic fertilizer (high content in nitrogen, phosphorus and potassium) or a cause of histoplasmosis than as a proxy for past vegetation and bat diet reconstructions.

\subsection{Incorporation modes of pollen and spores into bat guano}

Three main mechanisms have been recognised by which pollen and spores can become incorporated into bat guano.

1) The dominant mechanism is direct ingestion of insects, that are themselves covered by pollen or whose digestive system contains pollen (Pendleton et al., 1996), by the bats. Hence, if the insects have been feeding on nectar, the pollen assemblage originates mostly from insect-pollinated plants. In some cases, when the insects are not feeding on nectar, they may become covered by pollen found in the air; and hence, the guano is mostly dominated by anemogamous plant pollen (Maher, this volume).

2) Pollen may also be incorporated into bat faeces, together with fragments of bat skin and hair (Darnton et al., 1999), as a result of direct ingestion during grooming, since "the bat itself serves as a furry trap for airborne pollen" (Maher, 1992; this volume). In this way the bat ingests both insecttransported and wind-borne pollen.

3) A third mechanism is, by comparison with those previously mentioned, passive and indirect. This arises through the effects of air currents, generated by temperature differentials between the air in the cave system and that outside. This may carry pollen and spores far inside the cave (Coles and Gilbertson, 1994), there to settle as dust on the guano.

For points 1 and 2, it is interesting to note that pollen remains in the bat stomach for a relatively short period of time with most of the transit time spent in the intestine where the pollen content is extracted by enzymatic action through osmotic shock (Herrera and Martínez del Río, 1998). Experimentation has shown that total time between ingestion and defecation is usually quite short, a matter of a few hours. Exine is, with some rare exceptions, highly resistant to degradation by most digestive enzymes.

\subsection{Previous palynological analyses of guano}

The number of fossil bat guano palynological analyses remains low (Bui-Thi and Girard, 2000; Camacho et al., 2000; Maher, 1992, this volume) (pers. comm. from: M. F. Sanchez-Goñi (Bordeaux, France), and O. Davis (Arizona, USA)). Few palynologists have recognised the potential significance of bat guano in 1) addressing the problem of the under-represented entomogamous flora in the conventional palynological diagrams from sedimentary sequences (e.g. peat, lake sediment, marine sediment) and 2) contributing to the knowledge of the ethology of Cheiropters.

\subsection{Dating of bat guano}

A significant advantage of guano from insectivorous bats is that it is easily datable by radiocarbon as it is very rich in organic matter. Guano having usually a low $\mathrm{pH}$ (4 to 6 depending on the type of food) 
tends to dissolve any fragments of limestone that might have been mixed with it. In addition although fungal and bacterial activity takes place at the surface of the guano accumulation, there is no photosynthesis in caves. Although some of the earliest radiocarbon dates were from bat guano from the Carlsbad Cavern in New Mexico, there are still surprisingly few radiometric dates for bat guano. A 2.5 $\mathrm{m}$-thick bat guano deposit in an active roost in Romania has been dated to a Boreal time of formation (Carbonnel et al., 1996, 1999). Two radiocarbon dates indicate accumulation rates between 0.23 (oldest part of the deposit) and 0.44 (youngest part) mm. $\mathrm{yr}^{-1}$. The bat colony of this cave (diverse but dominated by Rhinolophus euryale) is one of the oldest permanent colonies in Europe, probably established just after the last Ice Age. In a cave at Arcy-sur-Cure (Yonne, France), Rhinolophus sp. guano deposits (up to $0.70 \mathrm{~m}$ thick) were dated to the Middle-Ages by several radiocarbon dates. An accumulation rate of $0.44 \mathrm{~mm} . \mathrm{yr}^{-1}$ was estimated. The cave was occupied by bats from before the VIII ${ }^{\text {th }}$ C. to XIX ${ }^{\text {th }}$ C. (i. e. for at least 1200 years) (Bui-Thi and Girard, 2000). In Missouri, the base of a 0.70 $\mathrm{m}$ thick bat guano heap from Myotis grisescens has been dated to $2810{ }^{14} \mathrm{C}$ years $\mathrm{BP}$ (Maher, this volume). Bat guano, up to $0.30 \mathrm{~m}$ thick, dating from last interglacial $\left(>38,000{ }^{14} \mathrm{C} \mathrm{yr} \mathrm{BP}\right)$ has been found in Mammoth Cave, Kentucky (Jegla and Hall, 1962).

\section{4 A source of information on ancient and modern bat roosts}

Bats throughout most of the year produce guano, though in larger quantities during the summer. A colony may flourish for several decades, possibly several centuries or even millennia. The Romanian cave study has shown that the longevity of a roost may extend beyond the Holocene. The French investigations provide evidence for the decline of a roost, established at least by early Medieval times, owing to the recent disturbance by tourism.

Modern bat guano has been studied by biospelaeologists and bat biologists in order to understand the feeding habits of bats and their circadian movements. This has sometimes included the study of the pollen content of modern guano samples (Herrera and Martínez del Río, 1998).

\subsection{Rhinolophus hipposideros}

It is important to understand the behaviour of the bat in order to understand the path followed by the pollen between the flower and the guano.

Rhinolophus hipposideros has shown a marked decline in numbers and a contraction in its distribution particularly in western and northern Europe (i. e. at its northern limit), although there is evidence of a recent population increase in Wales since 1993 probably due to conservation measures (BCT, 2002). $R$. hipposideros is rare in the British Isles and is confined to Wales, western England and western Ireland. The International Union for the Conservation of Nature (IUCN) has listed it as an endangered species.

Its typical diet comprises Diptera (mainly midges), Trichoptera, small Lepidoptera and Arachnaea (BCT, 2002). Although there are peaks of activity at dusk and dawn, bats are active all night throughout the breeding season. They feed amongst vegetation in sheltered lowland valleys near water and in damp wooded areas, flying close to the ground, rarely more than $5 \mathrm{~m}$ high, with frequent circling over favoured areas and often gleaning their prey off stones and branches (BCT, 2002; Vaughan, 1997). Large prey items are often taken back to a temporary night roost or sometimes eaten whilst hanging in trees. Feeding remains are found in such places, particularly in porches and the entrance of tunnels. They rarely forage further than $7 \mathrm{~km}$ away from shelter.

The formation of guano heaps or sheets depends on the density of the roost. In general, the Lesser Horseshoe bat is gregarious (BCT, 2002). The bats often have distinct summer and winter roosts. Lesser Horseshoe bats were originally cave dwellers, but summer (maternity) colonies (from April) are now usually found in the roofs of larger rural houses and stable blocks that offer a range of roof spaces. Nearby cellars, caves or tunnels provide environments where the bats can go torpid in inclement weather. The whole colony may form a dense cluster, especially in cooler weather during lactation, but if the roost gets very hot they hang spaced slightly apart.

During the winter, the Lesser Horseshoe Bat uses caves, mines, tunnels and cellars as hibernation sites. From October until April, Lesser Horseshoe bats are often active in the hibernacula in autumn and spring especially towards dusk in warm weather, when feeding is more likely to be successful. The 
hibernation is profound from December to March only, when they are not known to come out into the open. Nowadays, many sites have only one or a few bats hibernating in them and it is rare to find large numbers at a site. Even when aggregated, Lesser Horseshoe bats do not cluster but hang a little apart from their neighbours, usually exposed, but sometimes in open crevices. They may be found from almost ground level to over $20 \mathrm{~m}$ high and venture much further into underground sites than other bats. $R$. hipposideros returns faithfully to both summer and winter roosts every year (Warren and Witter, 2002). Destruction of such roosts can therefore be a major cause of population decline.

\section{Rhinolophus hipposideros guano in the Ogof Draenen cave system, south-east Wales}

In this section, a description of the cave system, the guano deposits and the present-day occurrence of bats in the area are given.

\subsection{Cave system}

The site is located in the south-east of the Brecon Beacons National Park, south-eastern Wales (inset in fig. 1). In this area a relatively narrow outcrop of Carboniferous Limestone forms a prominent scarp below an extensive upland area developed on younger Carboniferous sandstones and shales, and overlooks the extensive lowlands of the Usk valley developed largely on Old Red Sandstone (Devonian) (fig. 1). The Ogof Draenen and Agen Allwedd cave systems (5 km apart) are developed entirely in the limestone but both extend for a considerable distance beneath the younger Carboniferous cover (fig. 1) (Simms, 1998; Simms et al., 1996).

A number of major cave systems (> $10 \mathrm{~km}$ of passages) have been explored in south-east Wales (Waltham et al., 1997) of which at least one, Agen Allwedd (fig. 1), beneath the plateau of Mynydd Llangattwg, has been known as an important roost for the Lesser Horseshoe bats since at least its discovery more than 50 years ago. Ogof Draenen (fig. 1 and 2) is the most recent major cave discovery, being first entered in 1994. More than $70 \mathrm{~km}$ of passages have been explored to date over a vertical range of $148 \mathrm{~m}$ (Simms et al., 1996; Waltham et al., 1997). Ogof Draenen is located only $5 \mathrm{~km}$ to the south-east of Agen Allwedd, although separated from it by the deep valley of the River Clydach (fig. 1). The limestone along the scarp has been extensively quarried since at least the mid-XVIII ${ }^{\text {th }} \mathrm{C}$. The Coal Measures on the hilltop (south, around Pwl Ddu and Blaenavon) have been mined for at least a similar length of time (fig. 1), with the Blaenavon region recently designated a World Heritage Site for its XVIII ${ }^{\text {th }} \mathrm{C}$. industrial archaeology, but all of these workings have now been disused for several decades. Industrial activity in the past, particularly quarrying and the dumping of coal mine spoil, may have caused the collapse of some cave entrances, perhaps including that thought to have been used by the bats when they populated Ogof Draenen (fig. 3). Two small streams descend the scarp adjacent to the guano-rich areas of the cave and their incision has truncated some of the more ancient passages within the cave (fig. 2). A small lake, Penn-ffordd-goch, or Keeper's, Pond, is located on the hilltop about 500 metres to the south-east of the guano-rich parts of the cave and itself lies above other passages on the eastern side of the cave system (fig. 2).

\subsection{Guano deposits}

In Ogof Draenen, in places, the guano covers several $\mathrm{m}^{2}$ to a depth of several $\mathrm{cm}$, while elsewhere it forms conical heaps $>0.5 \mathrm{~m}$ in depth up to $4.5 \mathrm{~m}^{2}$ in area (location of heaps and sheets in fig. 3, brief description in table 1). Some Tropical caves may contain accumulations of guano several metres thick, for example $10 \mathrm{~m}$ in the Niah caves in NE Sarawak (M. I. Bird, pers. comm. 2002). In the British Isles, the Ogof Draenen guano volumes are unmatched by any other cave system. Typically the thick guano accumulations in Ogof Draenen are reddish-brown in colour and rather friable on their surface. Colour and texture do not differ perceptibly in appearance from that found in the active roosts only a few kilometres away. White fungal hyphae frequently pervade the surface layers of the guano. Beneath the surface the guano may be significantly darker and more compact, but dry. The size and shape of individual pellets indicates derivation of the guano very largely, if not exclusively, from Lesser 
Horseshoe bats (Rhinolophus hipposideros) and this is confirmed by skeletal remains commonly associated with the guano (see sample 12, table 1).

The extensive guano deposits in Ogof Draenen are also anomalous in that the site is no longer a major bat roost. These guano-rich areas all lie fairly close (within a few hundreds of metres) to the present scarp of the deep valley with several adjacent passages terminating in boulder chokes close to the present surface; some of these may represent former entrances since blocked by collapse (fig. 3 ).

\subsection{Bat colonies}

A small chamber, Siambre Ddu, located directly above the main Ogof Draenen system (fig. 2 and 3) but connected to it only by a boulder-choked shaft, is an important summer and early winter roost for Lesser Horseshoe and some rare Greater Horseshoe bats. However, its close proximity to the surface entrance makes it vulnerable to rapid temperature changes and hence not suitable for cold winter roosting.

Very few bats have been seen in the main cave system, i. e. Ogof Draenen, either in summer or winter. The few bats seen today are mostly Lesser Horseshoes (Rhinolophus hipposideros), but occasional Greater Horseshoes (Rhinolophus ferruequinum) and Daubentons (Myotis daubentonii) are also recorded.

Numbers using the Agen Allwedd cave system today far exceed those for Ogof Draenen and Siambre Ddu. Agen Allwedd cave currently has one of the largest active winter roosts for Lesser Horseshoe bats in Britain (Eurobats, 2002) with only very rare myotids $(<1 \%)$. Records show their numbers at this site to have increased to several hundreds over the past two decades (Chelsea Spelaeological Society, unpublished records, 2002). This cave is a good winter roost as the main roosting site is $>200 \mathrm{~m}$ from the entrance and hence it has maintain a stable temperature throughout the year.

\section{Past and modern vegetation, location and origin of the samples}

The fossil guano samples have been compared with two modern guano samples in order to assess temporal differences between them. Two samples from more conventional sources, lake mud and moss polster, have been taken from the area outside the cave in order to estimate the modern pollen rain and to assess the bias in vegetation reconstruction due to taphonomical difference between them and guano.

\subsection{Past regional composition and cover}

Human occupation is known in the Brecon Beacons since the Mesolithic (Rosen, 1998). The Bronze Age has left a series of dated cairns (Chambers, 1982). The Roman town of Caerwent lies only some 20 $\mathrm{km}$ to the south-east and Roman forts are known at Usk, Abergavenny and Brecon, implying the presence of significant local populations at this time. Abergavenny is also known as a Medieval town. Information available on the local vegetation for the Iron Age-Medieval period mainly emanates from palynological analyses of peat. In Cefn Glas (near Hirwaun, Glamorgan, $490 \mathrm{~m}$ asl), heathy vegetation replaced a more wooded, hazel-dominated, vegetation some 2500 cal. yr ago. An intensification of arable agriculture and increase of soil erosion during the Romano-British times (c. $1800 \mathrm{yr}$ ago) seems to have been clearly established (Smith and Green, 1995). The Dark Ages are generally considered a period of relative woodland recovery in Wales despite a lot of local variations (Rosen, 1998).

A blanket peat at site BB in the Brecon Beacons (715 m asl) (Chambers, 1982) and a moorland south the Brecon Beacons (Coed Taf, 400-420 m asl; Chambers, 1983) indicate in the area the presence of a progressively opening hazel woodland with birch, alder and oak over the last 2300 years. In Cefn Glas, Coed Taf and also in site BB, Ilex and Hedera are very rare and always have percentages below 1, whilst Acer is absent.

The pollen diagram of Ffoston Cenglau (a site at $488 \mathrm{~m}$ altitude, next to Cefn Glas) indicates for the period AD cal. 1360-1560 (the base of the diagram) a very open upland landscape with only $15-20 \%$ of trees and shrubs: $10 \%$ Corylus, 5\% Quercus, $<5 \%$ of Alnus and Betula. Acer is present in traces only, while Hedera and Ilex are absent (Rosen, 1998).

A palynological diagram covering the last 500 years from Crymlyn bog, Lower Swansea Valley, South 
Wales, shows for the XVI ${ }^{\text {th }}$ C. a local birch-hazel woodland with some remnants of an oak forest on better soils (Rosen and Dumayne-Peaty, 2001).

\subsection{Local and regional vegetation}

Today, the area is relatively open with grassland in the valleys and heathland on the plateaux, the woodland being preserved only in patches along the limestone scarp.

A full vegetation survey for Gilwern Hill and for the Mynydd Llangattock Sites of Special Scientific Interest (SSSI) have been undertaken by the Countryside Council for Wales (CCW) (fig. 1 and 2). Gilwern Hill reserve lies approximately $600 \mathrm{~m}$ to the north-west of Siambre Ddu, and adjacent to the northern part of Ogof Draenen (fig. 1 and 2). This area probably represents the main feeding area for the extant bats. The scarp above Cwm Llanwenarth (fig. 2) is of rough grassland or scrub, with areas of woodland with a canopy dominated by Fraxinus excelsior, with occasional Quercus robur and Betula pubescens. The shrub layer is usually fairly dense with Corylus avellana, Crataegus monogyna, Ulmus glabra (although numbers have been dramatically affected by the Dutch Elm Disease), Sorbus aucuparia and Acer campestre. Adjacent hilltops are of rough grassland or heathland. Large patches of the recent invasive plant, Impatiens glandulifera, have been observed in the valley of River Usk (fig. 1). The introduced Acer pseudoplatanus has become common.

The vegetation survey classifies the woodland near Siambre Ddu in the woodland community of Fraxinus excelsior, Acer campestre and Mercurialis perennis whereas the modern vegetation near Agen Allwedd is a woodland community of Fraxinus excelsior, Sorbus aucuparia and Mercurialis perennis.

In addition, for the interpretation of the two modern pollen rain samples (mud and moss), the vegetation at a greater distance needs to be mentioned: conifer plantations are frequent in this part of Wales since the XVIII ${ }^{\text {th }} \mathrm{C}$. and include a range of non-native taxa.

\subsection{The two modern pollen rain samples}

As the aim of this paper is not to characterize in detail the modern rain of the area but more to emphasise the difference between taphonomic processes and to obtain a first estimate of the difference between old and modern guano, two modern rain samples have been judged sufficient.

The moss polster and the lake mud have been collected by hand. They are expected to have trapped pollen and spores over several seasons, if not years, and hence represent the regional vegetation.

The mud sample comes from Pen-ffordd-goch, or Keeper's, Pond (NGR SO 25491079) (fig. 2). It was collected on 25 Feb. 2000, from a shallow area with bulrush (Typha sp.) on the south side of the permanent pond. The modern vegetation around this site is rough grassland with abundant heather.

The moss polster sample was collected in Sept. 1999 from below trees around the modern entrance of Ogof Draenen (fig. 2). The modern vegetation around this site is rough grassland with some Crataegus and Prunus.

\subsection{The two modern guano samples}

Guano from the small cave of Siambre Ddu (fig. 2 and 3) has been collected on 21 Aug. 2000 from a small patch. The modern vegetation around this site is rough grassland, marshy in places, with a few Crataegus monogyna and Prunus spinosa.

The sample from Agen Allwedd (fig. 1) was collected in 31 Jan. 1998 from a small guano patch in the entrance series of this cave. The cave entrance is located in rough grassland and bushes of Crataegus and Prunus.

The modern guano samples may contain only a seasonal signal but owing to the way the samples have been taken, they are likely to encompass more than a year, although the preferential usage as a summer/early winter or full winter roost may have an impact on the palynological spectra.

\subsection{Fossil guano sampling in Ogof Draenen}

Small guano samples (a few $\mathrm{cm}$ thick) were collected using a spoon (fig. 3 and table 1). Coring of guano accumulations was not possible owing to its loose nature, but attempts were made at some 
locations to collect stratigraphic samples. All of the material remaining after analysis has been retained in the Geology collections of the Ulster Museum (catalogue numbers BELUM K29624 to K29650).

\section{Material and methods}

All surveyed heaps and sheets are marked on fig. 3 and listed in table 1. Some of these sites have been studied for their pollen content, some have been dated and only one has been studied for its insect content (table 2).

The palynological extraction technique is not uniform due, on one hand, to different material to be treated and, on the other hand, to the move to another laboratory. The mud sample has been soaked in $\mathrm{Na}_{4} \mathrm{P}_{2} \mathrm{O}_{7}$, then $\mathrm{HCl}, \mathrm{HF}, \mathrm{HCl}$, sieved at 250 and $10 \mu \mathrm{m}$, no acetolysis, mounted in silicone oil. The moss sample were treated as above, and also acetolysed.

A typical guano sample is made of several tens if not hundreds of pellets, thus providing an averaging of several days, if not years.

For the two modern guano samples, the treatment included: $\mathrm{Na}_{4} \mathrm{P}_{2} \mathrm{O}_{7}, \mathrm{HCl}, \mathrm{HF}, \mathrm{HCl}$, acetolysis, sieving through 250-10 $\mu \mathrm{m}$, mounting in glycerol. For the fossil guano, the extraction method was applied to 2 $\mathrm{ml}$ of the sample and comprised $\mathrm{Na}_{4} \mathrm{P}_{2} \mathrm{O}_{7}$, warm $\mathrm{KOH}$ followed by acetolysis and 120-10 $\mu \mathrm{m}$ sieving. The scarcity of the mineral fraction allowed to avoid the acid attacks. The residue was then mounted in glycerol. The number of indeterminable grains is very low, confirming the excellent preservation of the pollen grains and spores despite ingestion by bats.

The palynological diagrams are built in percentages of terrestrial pollen, excluding the aquatics and spores, whose sum is the same terrestrial sum. The sum is always $>300$ pollen grains. The psimpoll software was used for plotting the diagrams (Bennett, 2003). Detrended Correspondence Analysis (DCA) in the psimpoll software package was applied to all 14 samples and all terrestrial taxa with the exception of aquatics and spores (60 taxa). The dataset for analyses has been recalculated as proportions. Score axis one represents $47 \%$ of the variance and axis two: $18 \%$.

All the fossil guano samples are from the Lesser Horseshoe bats (Rhinolophus hipposideros). Owing to the way the samples were collected and the way a heap builds up (Maher, this volume), it is possible that the radiocarbon samples are slightly diachronous. Six radiocarbon dates are available. One date ( $>150 \mathrm{~g}$ ) has been provided by the Radiocarbon Laboratory of Queen's University of Belfast by the high precision conventional method. Five dates come from the Poznan Radiocarbon Laboratory.

The insects were examined under a 60x stereomicroscope after soaking the guano pellets in water (P. Whitehead, pers. comm.).

\section{Results of the palynological analysis of modern samples}

The modern samples of guano, moss and mud are discussed with the emphasis on comparison to vegetation and also on taphonomical aspects.

\subsection{The modern pollen rain samples}

The moss polster sample is largely dominated by Pteridophytic spores (Dryopteris filix-mas, Pteridium aquilinum and various psilate Trilete spores) (fig. 5). Amongst the terrestrial taxa, the arboreal taxa (AP) are the most abundant with Pinus (20\%) and Betula (17\%). The other conifer pollen grains are represented by Abies, Picea and Tsuga and the other deciduous tree grains by Quercus (6\%), Fraxinus excelsior (4\%), Alnus, Corylus and Fagus. Calluna pollen reaches $5 \%$. The most common nonarboreal pollen (NAP) taxa are Gramineae (23\%), Rosaceae $(7 \%)$ and Plantago lanceolata. The abundant Rosaceae pollen grains are most likely originating from the varied local bushes and herbaceous vegetation.

For the lake mud sample, the AP (42\%) are not dominated by one taxa but on the contrary contain many arboreal taxa: Corylus (9\%), Quercus (7\%), Betula (5\%), Alnus and Fraxinus excelsior (4\%) (fig. 5). A few grains of evergreen oaks have been encountered. This is likely from Quercus ilex, a Mediterranean oak that is now self-sown in Wales. The NAP contain large numbers of Gramineae (38 
$\%)$. Heather is well represented by Calluna (8\%) and other Ericaceae (6\%). Other NAP are relatively diverse but with very low values. The sample contains abundant Sphagnum spores.

\subsection{The modern guano samples}

Both samples are dominated by tree pollen, with a clear over-representation of insect-transported pollen (fig. 5).

- In Agen Allwedd, Salix values (28\%) are followed in importance by Fraxinus excelsior (11\%), and then Betula and Quercus both with $10 \%$. The good representation of the pollen of Acer (5\%), Ilex (4 $\%)$, Alnus (3\%) and Sambucus racemosa (2\%) is noticeable. Corylus and Ulmus each reach less than $1 \%$. Amongst the NAP, Ranunculaceae (14\%) and Rosaceae (2\%) are the best represented with some Gramineae and Umbelliferae.

- In Siambre Ddu, the pollen spectrum is different with less tree pollen (41\%). Hedera pollen $(20 \%)$ largely dominates. Of secondary importance are: Acer (5\%), Fraxinus excelsior (4\%), Betula (3\%), and Quercus, Corylus and Salix each with $2 \%$. Some rarer grains of Fagus, Castanea, Alnus, Taxus and Ilex are observed. The non-arboreal pollen grains are dominated by large numbers of Impatiens glandulifera $(16 \%)$ and by Gramineae $(16 \%)$. Various other NAP are well represented with: Asteraceae liguliflorae and Plantago lanceolata (both at $4 \%$ ), Rubiaceae and Urticaceae (both at $3 \%$ ) and Ranunculaceae (2\%).

- In Siambre Ddu, one grain of Olea has been encountered. It is impossible to totally exclude a laboratory contamination (although no other similar contamination has been observed). It is therefore necessary to explain its presence in the guano if genuine. Large-scale migrations of many species of both day- and night-flying macrolepidoptera, such as Autographa gamma (Silver Y), Macroglossum stellatarum (Humming-bird Hawk-moth) and Vanessa atalanta (Red Admiral), regularly occur from southern Europe to Britain. It is quite conceivable that the Olea grain was carried on the body of such an insect that was then ingested by the bat on arrival in this area. It does not imply any large-scale migration of insects or, even less so of bats, but it does have potential implications for the interpretation of ancient pollen spectra derived from bat guano.

- The two samples are different (fig. 6), showing a seasonal bias: in Agen Allwedd, Salix and Rosaceae have blooming times in later winter and early spring whereas in Siambre Ddu Hedera and I. glandulifera bloom in late summer and early autumn. Two different, but concordant, reasons for this may be invoked: 1) the time of the sample collection in January for Agen Allwedd and in August for Siambre Ddu; and 2) the time of the year when the cave is occupied: Agen Allwedd is mostly used as a full winter roost while Siambre Ddu is mostly used in early winter.

\subsection{Comparison}

The differences between the guano samples and the mud and moss samples are:

- the greater representation of insect-transported taxa in the guano,

- the almost complete absence of spores in the guano,

- the recent conifer plantations reflected only in the mud and the moss samples as part of the regional pollen rain,

- the insect-pollinated invasive Indian Balsam in one of the modern guano samples,

- the heathland represented in the mud/moss samples only, as it is probably not a preferential hunting ground for the bats.

\section{Dating results}

The radiocarbon dates with their calibrated ages are presented in table 2 . The six dates place the active occupation by Lesser Horseshoe bats, of at least this part of the cave, during the Iron Age to Medieval period (2400 to $835{ }^{14} \mathrm{C}$ years BP). Two dates cluster around cal. AD 100-200 and two others around cal. AD 900-1000. The two samples in heap 9 are in chronological order and indicate that the heap formed over $750{ }^{14} \mathrm{C}$ years. 


\section{Palynological results of the fossil guano}

\subsection{Fossil guano}

Identification of arthropod remains in sample D has proven difficult as a consequence of the fine mastication of material by the bats and the presence of the enzyme chitinase within the gut of Horseshoe Bats (K. McAney, pers. comm.). Only very fragmentary remains of Culicidae (Diptera) could be identified with any certainty. Both male and female Culicidae eat nectar, and hence act as important pollinators.

The ten fossil pollen spectra are dominated by Ilex (8-33\%), Quercus (4-24\%) and Betula (2-23\%). Subsidiary arboreal pollen taxa are: Hedera (1-41\%), Acer (0-21\%), Corylus (3-26\%), Salix (3-12 $\%)$. The non arboreal pollen (NAP) is relatively low and dominated by Rosaceae percentages (up to 35 $\%$ ). When the arboreal pollen (AP) values fall below $90 \%$, it is owing to the good representation of the Rosaceae, placed here in the NAP, although this family contains plants from the herb size to that of trees. The results of the DCA indicate that all the fossil samples are fairly close to each other (fig. 6). The fact that they are not tightly clustered mostly comes from the seasonal component, and not their age.

\subsection{Comparison modern/fossil guanos}

The two modern guano spectra fall outside of the group made by the fossil ones (fig. 6) with however Siambre Ddu close to the moss and mud owing to its high grasses content,.

\section{Discussion}

Results related not only to the deposit and past vegetation but also to past Chiropteran behaviour may be derived from this study.

\subsection{The deposit}

1 - Most of the fossil samples present a remarkable similarity in pollen assemblages (fig. 5 and 6) indicating that during the time span represented by the deposits (Iron Age to Medieval period), the vegetation remained relatively stable.

2 - We may consider that the three modes of transport of the palynomorphs to the cave (ingestion of insects, grooming, air currents in the cave) are acting here together. Large cave systems, such as Ogof Draenen with more than $70 \mathrm{~km}$ of explored passages, generate powerful, seasonally reversing, draughts (well-known to cavers) due to the temperature differential between the surface and underground air temperatures.

3 - Spores are quasi absent in the guano, both in modern and fossil samples. Cave sediment however often is rich in spores (Coles and Gilbertson, 1994) transported by air from ferns growing at the humid cave entrance. The only sample that contains some spores, sample D, is indeed only $150 \mathrm{~m}$ from a potential entrance. The others are not influenced by vegetation growing at the cave entrance.

4 - The sedimentation rate obtained in heap 9 is hardly $0.16 \mathrm{~mm} \cdot \mathrm{yr}^{-1}(750$ years in $12 \mathrm{~cm}$ ) if continuous. This is low in comparison to Romania and France, where accumulation rates have been estimated between 0.23 and $0.44 \mathrm{~mm} . \mathrm{yr}^{-1}$. Preliminary dating of the guano in the Niah caves (M. I. Bird, pers. comm. 2002) indicates an accumulation rate of $0.19 \mathrm{~mm} \cdot \mathrm{yr}^{-1}$. The slow rate in Wales might be due to the roost location at the northern distribution limit of this species.

\subsection{Past vegetation}

1 - Several insect-transported taxa stand out as types that are rarely encountered in more than trace quantities in palynological spectra derived from conventional sources. These are Ilex and Hedera, Acer, Salix (to an extent), which here exceed in abundance Betula and Quercus. A recent vegetation survey of the adjacent Gilwern Hill Site reveals that both Hedera and Ilex are now rare.

2 -Local vegetation changed over time. Two thousand years ago, the forest was denser as reflected both by entomogamous and anemogamous species of trees. Especially oak seems to have been the dominant 
forest tree in the hunting grounds of the bats, possibly limited to the narrow strip made by the limestone scarp.

3 - The comparison to modern samples indicates heathland is not represented in guano, as the bats may not hunt there. The grassland is not represented in the fossil samples indicating its recent development. 4 - Guano is a good tool to obtain information on entomogamous plants otherwise under-represented in peat bogs and lake sediments.

\subsection{Chiropteran behaviour}

1 - In order to establish when the roost was used, the blooming times of the various flowers is considered. A pollen calendar constructed from pollen traps placed in Cardiff, on the south coast of Wales, provides us with their abundance in the air through the year over several decades (Proctor and Yeo, 1979). In March, Corylus, Ulmus, Taxus and Alnus are the first plants to produce many pollen grains. April is more characterised by Salix, Fraxinus and Betula. In May, Quercus, Pinus and Fagus are more abundant. In June, pollen grains of Gramineae, Plantago, Rumex, Urtica and Sambucus are abundant in the air. July sees more Gramineae, Plantago and Urtica, with the new appearance of Tilia, Castanea and Chenopodiaceae. In August, there are still quite a lot of Gramineae and Urtica and this month witnesses the new development of Artemisia and Calluna. Besides Urtica, Taxus and Castanea, all the mentioned taxa are found in the fossil guano. On the contrary it is interesting to note that Acer, Hedera and Ilex are absent from these air counts.

It may therefore be established that pollen from plants flowering through the whole year is present in the fossil guano. The fossil spectra indicate quite clearly that the Ogof Draenen cave was used both as summer and winter roosts. The awakening and feeding of bats during mild autumn days may explain the large representation of late flowering plants such as Hedera whose nectaries are the only ones then available for insects.

2 - It is not understood yet why the roost in Ogof Draenen was abandoned. In the British Isles, since the late $\mathrm{XX}^{\text {th }} \mathrm{C}$. $R$. hipposideros has declined. This has been attributed to several factors including disturbance to roosts and intensive agricultural practices such as the use of pesticides that decreases available food source. In the case of Ogof Draenen, additional negative factors such as the collapsed entrances and the industrial pollution might have been sufficient causes to explain an early roost decline. This study also showed that the composition of the forest changed with the reduction of the oak, ivy and holly in favour of heathland and grassland. This has a direct impact on food availability.

\section{Conclusion}

Palynological analysis of bat guano is important for supplementing data derived from pollen air traps and sediment in which insect-borne pollen taxa are under-represented. Combining this information into locally-derived datasets of wind-dispersed pollen and spores (such as peat bogs and palaeolimnological sequences) provides an opportunity to construct a more comprehensive vegetation record and floral list for the Holocene (Carrión, 2002). However, some caution must be exercised in the interpretation of pollen spectra since ingestion of migratory insects may introduce exotic pollen taxa into samples.

Guano-rich caves may be found in karstic area where lakes and peat bogs are rare and hence fill gaps in the geographical coverage when reconstructing past vegetation.

The main results are:

- the fossil deposit of bat guano in the section of the cave of Ogof Draenen that we studied formed between 2400 and $883{ }^{14} \mathrm{C}$ yr BP;

- the accumulation rate of one of the heaps was $0.16 \mathrm{~mm} \cdot \mathrm{yr}^{-1}$;

- the woodland was then denser with more oak, holly and ivy than at present;

- the fossil roost was occupied both in summer and in winter.

In addition to the usual threats to bats, we have to add over time a change in the composition of the vegetation cover (more heathland and grassland) and extensive collapse of cave entrances (natural and human-made). 


\section{Acknowledgements}

We are grateful to the Queen's University of Belfast Radiocarbon Laboratory for the guano radiocarbon dating and to Philip Collins (Brunel University) for critical reading of the manuscript.

We extend our thanks to the sample collectors: Andy Farrant (British Geological Survey) for fossil guano and for modern muds, Tim Guilford (University of Oxford) for moss polsters, and to Paul Whitehead, freelance landscape consultant (Pershore, Worcestershire, UK), for insect identification.

\section{References}

BCT, 2002. Site of the Bat Conservation Trust in the UK. www.bats.org.uk, Visited in Dec. 2002.

Bennett, K., 2003. psimpoll software on http://www.kv.geo.uu.se/psimpoll.html

Bronk Ramsey, C., 2000. Comment on 'The Use of Bayesian Statistics for ${ }^{14} \mathrm{C}$ dates of chronologically ordered samples: a critical analysis', Radiocarbon, 42, 2, 199-202

Bui-Thi, M., Girard, M., 2000. Les guanos de chauve-souris d'âge médiéval de la Grande Grotte d'Arcy-sur-Cure (Yonne). Analyse pollinique et implications paléobotaniques. Géologie Alpine Mém. H. S. 31, 83-95.

Camacho, C.N., Carrión, J.S., Navarro, J., Munuera, M., Prieto, A.R., 2000. An experimental approach to the palynology of cave deposits. Journal of Quaternary Science 15, 6, 603-619.

Carbonnel, J.-P., Decu, V., Olive, P., Povara, I., Gheorghiu, V., 1996. Première datation par ${ }^{14} \mathrm{C}$ du remplissage de guano d'une grotte des Carpates méridionales: Pestera lui Adam (Roumanie). Trav. Inst. Spél. "Emile Racovitza" 35, 143-152.

Carbonnel, J.-P., Olive, P., Decu, V., Klein, D., 1999. Datations d'un dépôt de guano holocène dans les Carpates méridionales (Roumanie). Implications tectoniques. C. R. Acad. Sci. Paris 328, 367-370.

Carrión, J. S., 2002. A taphonomic study of modern pollen assemblages from dung and surface sediments in arid environments of Spain. Rev. Palaeobot. Palyn. 120, 217-232.

Chambers. F. M., 1982. Two radiocarbon-dated pollen diagrams from high-altitude blanket peats in South Wales. Journal of Ecology 70, 445-459.

Chambers, F. M., 1983. Three radiocarbon-dated pollen diagrams from upland peats north-west of Merthyr Tydfil, south Wales. Journal of Ecology 71, 175-487.

Coles, G. M., Gilbertson, D. D., 1994. The airfall-pollen budget of archaeologically important caves: Creswell Crags, England. Journal of Archaeological Science 21, 735-755.

Darnton, B., Parmentier, J., van Egmond, W., 1999. Making a study of bat droppings. http://www.microscopy-uk.org.uk/mag/artapr99/bdbat.html. Visited in Dec. 2002.

Eurobats, 2002. $\quad$ EUROBATS, AC5, Report Annex 3. www.eurobats.org/finalreports/AC5/RecordAnnex3-habitats.htm. Visited in Dec. 2002.

Jegla, T. C., Hall, J. S., 1962. A Pleistocene deposit of the free-tailed bat in Mammoth Cave, Kentucky. Journal of Mammology 43, 4, 477-481.

Herrera, L. G., Martínez del Río, C., 1998. Pollen digestion by New World bats: effects of processing time and feeding habits. Ecology 79, 8, 2828-2838.

Maher, L.J. Jr., 1992. Palynology of bat guano may provide a useful climate record. $8^{\text {th }}$ International Palynological Congress, Aix-en-Provence, France, Programs and Abstracts, p. 96.

Maher, L.J. Jr., this volume. Environmental information from the palynology of bat guano. Palaeogeography, Palaeoclimatology, Palaeoecology.

Pendleton, M. W., Bryant V. M., Pendleton, B. B., 1996. Entomopalynology. In: Palynology: principles and applications. Jansonius J. \& McGregor D. C. (ed.). AASP 3, 939-943.

Proctor, M., Yeo, P., 1979. The pollination of flowers. Collins, London.

Rosen D., 1998. Recent palaeoecology and industrial impact on the South Wales landscape. Unpublished $\mathrm{PhD}$ thesis, University of Wales, Swansea.

Rosen, D., Dumayne-Peaty, L., 2001. Human impact on the vegetation of South Wales during late historical times: palynological and palaeoenvironmental result from Crymlyn Bog NNR, West Glamorgan, Wales, UK. The Holocene 11, 1: 11-23. 
Simms, M., 1998. Caves and karst of the Brecon Beacons National Park. British Cave Research Association. Cave Studies series 7, 32 pp.

Simms, M., Farrant, A., Hunt J., 1996. Ogof Draenen, where did it come from and where will it go? Caves and Caving 71, 10-13.

Smith, A. G., Green, C. A., 1995. Topogenous peat development and late-Flandrian vegetation history at a site in upland South Wales. The Holocene 5, 2: 172-183.

Stuiver M., Reimer, P.J., Bard, E., Beck, J.W., Burr, G.S., Hughen, K.A., Kromer, B., McCormac, G., van der Plicht, J., Spurk, M., 1998. INTCAL98. Radiocarbon Age Calibration, 24000-0 cal. BP Radiocarbon 40, 3, 1041-1083.

Vaughan, N., 1997. The diets of British bats (Chiroptera). Mammal Review 27, 2, 77-94.

Waltham, A. C., Simms M. J., Farrant, A. R., Goldie, H. S., 1997. Karst and Caves of Great Britain: Geological Conservation Review Series, vol. 12. Chapman and Hall, London.

Warren, R., Witter, M., 2002. Monitoring trends in bat population through roost surveys: methods and data from Rhinolophus hipposideros. Biological Conservation 105, 255-261. 


\section{Tables}

Table 1: Field sample number, location in the cave and notes for the fossil guano samples in Ogof Draenen. Numbers in brackets refer to samples retained by the Ulster Museum. See figure 3 for the location map.

$1-0.30 \times 0.20 \mathrm{~m}$ patch, $\sim 0.02 \mathrm{~m}$ thick (K29624), with several other similar patches nearby. Lies directly beneath sharp edge formed by earlier blockfall.

$2-0.20 \times 0.15 \mathrm{~m}$ patch, $\sim 0.03 \mathrm{~m}$ thick (K29625). Lies below rough surface and edge formed by earlier blockfall.

$3-0.26$ x $0.23 \mathrm{~m}$ patch $\sim 0.035 \mathrm{~m}$ thick (K29626). Adjacent to rather smooth overhanging wall.

4 - Only a few very scattered bat faeces throughout Siambre Ddu Passage. Very sparse lines of guano below edge of undercut just north of junction with Megadrive.

5 - Very sparse scattering in this area. Sample (K29628) collected from $0.05 \times 0.05 \mathrm{~m}$ patch within boulder pile.

6 - Floor coated with mm-thick dark dust (?guano) layer.

7 - Largest single heap in cave system (photo in fig. 4), covering area of $2.50 \times 1.50 \mathrm{~m}$ and $\sim 0.50 \mathrm{~m}$ thick directly beneath irregular fractured overhang. Three samples collected; from top $2 \mathrm{~cm}$ (K29630), from 2 to $5 \mathrm{~cm}$ depth (K29631), and from 5 to $8 \mathrm{~cm}$ depth (K29632).

8 - Two large heaps either side of large undercut loop passage, directly beneath sharp edge of undercut. Each $\sim 1.0$ x $0.15 \mathrm{~m}$ and $\sim 0.05 \mathrm{~m}$ thick (K29633).

$9-1.0 \times 0.50 \mathrm{~m}$ and $0.12 \mathrm{~m}$ thick, directly beneath 'popcorn' coated overhang. Three samples collected; from top $2 \mathrm{~cm}$ (K29634), from 2 to $5 \mathrm{~cm}$ depth (K29635), and from 10 to $12 \mathrm{~cm}$ depth (K29636).

10 - Lines of guano 2 to $3 \mathrm{~cm}$ thick at foot of passage aligned directly beneath sharp edges of substantial undercut for $\sim 30 \mathrm{~m}$. Samples collected from top (K29637) and bottom (K29638).

11 - Abundant guano (K29639) several $\mathrm{cm}$ thick floors much of $0.40 \mathrm{~m}$ high and $1.5 \mathrm{~m}$ wide passage, with very rough roof, for several tens of metres.

12 - Patches up to $0.50 \times 0.30 \mathrm{~m}$ and $0.10 \mathrm{~m}$ thick. Guano samples collected from top $2 \mathrm{~cm}$ (K29640) and bottom $3 \mathrm{~cm}$ (K29641); dead bat collected (K29642).

13 - Two $0.20 \times 0.15$ x $0.01 \mathrm{~m}$ patches below edge of undercut. Roosting Lesser Horseshoe Bat. (K29643).

14 - Elongated heap of guano up to $0.14 \mathrm{~m}$ deep, stretching 2-3 $\mathrm{m}$ and following sharp edge of undercut, with greatest concentration directly beneath. Samples collected from top $2 \mathrm{~cm}$ (K29644) and from 3 to $5 \mathrm{~cm}$ depth (K29645).

15 - Several elongate heaps ( 1 $\mathrm{m}$ long and $0.2 \mathrm{~m}$ wide) below edge of undercut. One sample (K29646). 16 - Small patches (K29647).

17 - Scattered guano below undercut (K29648).

18 - Several heaps up to $0.40 \times 0.30 \mathrm{~m}$ and $0.10 \mathrm{~m}$ thick below edge or rough surface of overhang (K29649)

D - Extensive spreads of guano ( $>4 \mathrm{~m}^{2}$ and up to $10 \mathrm{~cm}$ thick) in passage $<1 \mathrm{~m}$ high but $>10 \mathrm{~m}$ wide. Sample taken from the top $0.04 \mathrm{~m}$ (K29650). 
Table 2: Sample list, their Ulster Museum number and their use for insect, pollen and ${ }^{14} \mathrm{C}$ analysis

\begin{tabular}{|l|l|l|l|l|}
\hline Sample & Number & Insect & Pollen & ${ }^{14} \mathrm{C}$ \\
\hline D & K29650 & $\sqrt{ }$ & $\sqrt{ }$ & $\sqrt{ }$ \\
\hline 3 & K29625 & & & $\sqrt{ }$ \\
\hline 7top & K29630 & & $\sqrt{ }$ & \\
\hline 9top & K29634 & & $\sqrt{ }$ & $\sqrt{ }$ \\
\hline 9middle & K29635 & & $\sqrt{ }$ & \\
\hline 9bottom & K29636 & & & $\sqrt{ }$ \\
\hline 10top & K29637 & & $\sqrt{ }$ & \\
\hline 10bottom & K29638 & & $\sqrt{ }$ & \\
\hline 12top & K29640 & & $\sqrt{ }$ & \\
\hline 12bottom & K29641 & & $\sqrt{ }$ & $\sqrt{ }$ \\
\hline 13 & K29643 & & $\sqrt{ }$ & \\
\hline 14top & K29644 & & $\sqrt{ }$ & $\sqrt{ }$ \\
\hline
\end{tabular}

Table 3: Calibration of the radiocarbon dates of the Ogof Draenen guano, Wales (Atmospheric data from Stuiver et al., 1998; OxVal v3.5 in Bronk Ramsey, 2000)

\section{Figure captions}

Fig. 1: Location of and geology associated with the Ogof Draenen and Agen Allwedd cave systems at the eastern end of the Brecon Beacons National Park, Wales, UK. Inset: the National Park of the Brecon Beacons.

Fig. 2: Plan survey of cave passages beneath the surface, including location of Siambre Ddu (modern guano) above Ogof Draenen and the moss (entrance of Ogof Draenen) and mud (Penn-fford-goch) sampling localities.

Fig 3: Simplified survey of part of the Ogof Draenen cave system showing the collapsed entrances and the location of samples collected during the course of this investigation. (Based on a survey by John Stevens and members of the Chelsea Spelaeological Society).

Fig. 4: Dated heap (site 7) in Ogof Draenen at the start of The Canyons (Photo: M. J. Simms).

Fig. 5: Pollen and spores diagram for modern guano, mud and moss samples and fossil guano samples. Black dots for values lower than $3 \%$.

Fig. 6: Plot of the two first axes obtained by Detrended Correspondence Analysis on modern and fossil pollen samples. Crosses: modern samples of mud and moss. Stars: modern samples of guano. Diamonds: fossil guano. In brackets next to the sample number; the uncalibrated radiocarbon date. 